\title{
Accompaniment needs of first year nursing students in the clinical learning environment
}

S Carlson, (M.Cur), Department of Nursing Science, University of Port Elizabeth WJ Kotzé, (D.Cur), Department of Nursing Science, University of Port Elizabeth D van Rooyen, (D. Cur), Department of Nursing Science, University of Port Elizabeth

\section{Abstract}

The clinical learning environment creates many opportunities for student learning and the development of critical competencies in the nursing profession. The learning that takes place in this environment, however, confronts the first year nursing student with challenges that are absent from the classroom situation and causes the student to experience a significant amount of uncertainty and anxiety.

The study revealed that the students experience uncertainty due to the lack of opportunities to develop competence in providing nursing care. The contributing factors towards this experience are: unavailability and inaccessibility of staff due to time constraints; shortage and/or absence of equipment to fulfil nursing duties and meet the needs of patients; conflict in the expectations of nursing school personnel and clinical nursing personnel in hospitals, as well as a lack of awareness among senior professionals of the needs and problems of first year nursing students in the clinical health care environment. Furthermore the students experienced the nature of the clinical learning programme as disrupting the continuity in patient care learning experiences, and the guidance and support by nursing personnel in the clinical learning environment as inadequate.

The aim of this study was to reflect the importance of effective accompaniment by tutors/mentors, personnel in the clinical environment and any other person involved in the education of the first year nursing student, to prepare and enable him/her to become a knowledgeable, safe, competent nursing practitioner.

\section{Key words}

Anxiety, clinical learning environment, accompaniment, development of essential competencies, first year nursing student, lack of opportunities

\section{Abstrak}

Die kliniese leeromgewing skep baie geleenthede vir studente om kritiese bevoegdhede in die verpleegberoep te ontwikkel. Die leer wat in dié omgewing plaasvind, konfronteer die eerstejaarverpleegstudent met uitdagings wat afwesig is van die klaskamersituasie. Dit veroorsaak dat die student ' $n$ groot hoeveelheid onsekerheid en angs ondervind.

Die studie het aangedui dat die student onsekerheid ondervind as gevolg van die gebrek aan geleenthede om bevoegdhede in die voorsiening van verpleegsorg te ontwikkel. Bydraende faktore tot die ondervinding is: onverkrygbaarheid en ontoeganglikheid van personeel as gevolg van beperkte tyd; tekort aan/of afwesigheid van toerusting om verpleegtake uit te voer en om in die behoefte van pasiënte te voorsien; konflik in die verwagtinge van verpleegskoolpersoneel en kliniese verpleegkundiges in die hospitaal asook die gebrek aan bewustheid by senior verpleegkundiges van die behoeftes en probleme van eerstejaarverpleegstudente in die kliniese gesondheidsorgomgewing. Verder het die studente die aard van die kliniese leerprogram as ' $n$ onderbreking in die deurlopenheid in pasiëntsorg leerervaringe ondervind. Die leiding en ondersteuning van verpleegpersoneel in die kliniese leeromgewing is ook onvoldoende.

Die doel van hierdie studie was om die belangrikheid van effektiewe begeleiding deur dosente/mentors, personeel in die kliniese omgewing en enige ander persoon betrokke by die opvoeding van eerstejaarverpleegstudente te reflekteer. Die student word dan voorberei en in staat gestel om te ontwikkel tot ' $n$ kundige, veilige en bevoegde verpleegkundige.

\section{Introduction}

In nursing education, learning opportunities for students at all levels of the programme have to facilitate learning and skills development within the parameters of their Scope of Practice.
The regulations determining these parameters are devised by the South African Nursing Council (SANC). The preface to these regulations R2598 of November 1984, as amended by R260 of 1991, determine the following as fundamental to the Scope of Practice as a nurse or midwife: “... or procedures, 
which may be performed by scientifically based physical, chemical, psychological, social, educational, and technological means applicable to health care practice." The basic nursing skills required of a nurse to master in her first year will be discussed within the parameters of her Scope of Practice and the context of the basic needs of patients, inter alia, "... the prescribing, promotion or maintenance of hygiene, physical comfort ..." and "supervision over and maintenance of elimination by a patient" (Regulation R.2598 in terms of the Nursing Act, 1978).

Whilst first year nursing students are performing activities related to patient care and nursing ie. basic nursing care, they are expected to complete a certain amount of clinical practical hours to meet programme requirements. Clinical practica involves clinical learning opportunities in health care settings under supervision of the registered nurse or registered midwife, and where appropriate, other knowledgeable and skilled persons (South African Nursing Council Terminology List, 1994a:5).

The first year students, who have just come from a sheltered school environment with its interpersonal nature, its discipline, regular hours, and study and leisure patterns, find themselves in a completely different world which presents strange experiences, and they have to adapt to the challenges inherent in clinical practica as well as in human suffering. They are subject to changes in mood, with heightened emotionality, which can be compounded by coming into contact with ill persons. Hence, there are bound to be times of emotional tension. Understanding on the part of the mentor, as well as other members of the health team, can do much to reduce this tension and prevent unnecessary dropping out (Mellish and Brink, 1990:53).

The number of first year nursing students varies from institution to institution. For the purpose of this study the researcher will focus on Baccalaureus Curationis students from the University of Port Elizabeth.

\section{Problem statement}

Within the first few months of nursing there are first year nursing students who resign because of the perception the student has of what is involved in being a nurse, and what they actually experience in the clinical learning environment. A study by Harvey and Murray (1997:383) indicates that early abandonment of the programme is related to unhappiness or poor performance of students.

In the experience of the researcher first year nursing students verbalized that they "did not like the practical side of nursing". This could be due to a number of factors that have been expressed by students to the researcher. These factors include:

1. Personal perceptions about the practicals and theory related to nursing

2. Long practical hours in the hospitals, getting to the hospital early and leaving late at night

3. Attitudes of registered nurses towards students. The researcher, being a lecturer and accompanier in the clinical environment, often hears the phrases "that sister always helps me" or otherwise "the sisters in this ward are not helpful at all. I always have to ask the senior students ..."

The first year nursing students are also accompanied in practice by the nurse teacher as clinical nursing supervisor (the accompanier). Accompaniment is directed assistance and support by a registered nurse or registered midwife to a student in order to become a competent practitioner. In the case of a student, growth occurs in relation to the level of independence. In the clinical practice area all registered nurses are indispensable in the accompaniment of the student (South African Nursing Council Terminology List, 1994:1).

4. Diminished resources in the hospitals. There is often a shortage of basic equipment and stock such as linen, liquid soap for hand washing, paper towels with which to dry hands, gloves for remaining surgically clean whilst performing nursing skills, disinfectants to spray hands

5. Communication and language barriers - the majority of first year nursing students are fulfilling practical hours in a provincial regional hospital where the main bulk of patients speak African languages. Students verbalize that they find it very difficult to communicate with patients especially if they want to educate them regarding their health needs, and design a plan of care to meet the needs of these patients eg. the African speaking students find it difficult to communicate with Afrikaans speaking patients, and vice versa. The English speaking students find it difficult to communicate with African speaking patients and some of them with Afrikaans speaking patients.

Due to the above-mentioned factors, first year nursing students become frustrated because they cannot fulfill their practical requirements effectively. First year nursing students perform practical examinations in the clinical learning environment. and they are required to be evaluated on their clinical skills. These students are expected to be competent in all skills related to their level of nursing practice.

Students also become very confused because of the discrepancies between what is theoretically taught and experienced in the practical field, the so-called "theory-practice gap". This is confirmed by Forrest, Brown and Pollock (1996:1258) who defined the issue of the theory-practice gap as the discrepancy between what is taught to student nurses in the classroom and what is practised in the clinical learning environment.

The students also experience a certain degree of conflict because of the difference in the manner in which they are taught skills and the manner in which skills are actually implemented in the clinical learning environment. When students perform the way they are taught, they are reprimanded by ward staff. A student, who was very confused because of this, approached the researcher and said that a nurse had told her "you are wasting our time by doing it that way". This has a definite impact on the way in which students perform and the fact that they want to render safe, effective patient care. This causes students to feel unsure and incompetent. The students also verbalized that they "become nervous when expected to perform for an examination or a competency where a mark is obtained for performance".

The needs of first year nursing students, especially within the first 3 - 4 months in the clinical learning environment need special consideration by the registered nurse and the clinical supervisor. They have the special task of giving support and guidance to these students. They must accompany them so that they, as students, can develop on a personal and professional level. 


\section{Research Objectives}

The objectives of the study were to:

- $\quad$ explore and describe the experiences of first year nursing students related to their exposure to the clinical learning environment.

- develop guidelines to ensure optimal accompaniment of first year nursing students in the clinical learning environment.

\section{Definition of Terminology}

\section{Accompanier}

This individual is the person who accompanies the student at any given time. It is/ could be the lecturer, the clinical supervisor, or the ward/unit registered nurse.

\section{Clinical learning environment}

The clinical learning environment is the environment in which students perform skills related to needs of patients and provide physical, psychological, spiritual and social support (utilizing a holistic approach) to patients, in order to promote and maintain safe, effective patient care (researcher's definition based on reviewed literature).

\section{Student}

An individual who is following the four year Baccaulaureus Curationis programme in the Department of Nursing Science of the University of Port Elizabeth.

\section{Accompaniment}

Accompaniment is the planned and deliberate intervention by the accompanier, and includes all those activities that occur in a planned fashion according to the needs of the student, and are aimed at inducing self-reliance in the dependent person (in the context of this study, the first year nursing student) (Kotzé, 1998:10).

\section{Research design and method Research design}

This research study was a qualitative, explorative, descriptive, contextual study, reflecting experiences of first year student nurses in the clinical learning environment.

\section{Research method}

The collection of data and the analysis of data was implemented and divided into two phases.

Phase $I$ jnvolved the exploring and describing of the experiences of first year nursing students whilst exposed to the clinical learning environment.

Phase 2 followed the interpretation of data and involved the development of guidelines to ensure optimal accompaniment of first year nursing students in the clinical learning environment. This will assist the clinical supervisor and all staff members working with first year nursing students in making the clinical learning environment less threatening for the first year nursing student and optimize their experience of the clinical learning environment.

\section{Method of data collection}

\section{Sampling}

Random-purposive sampling was used. Burns and Grove (1999:233) state that from a sampling point of view each individual in the population should have an opportunity to be selected for the sample. One method of providing this opportunity is referred to as random sampling.

Purposive sampling is judgmental sampling that involves the conscious selection by the researcher of certain subjects or elements to include in a study (Burns and Grove, 1999:475). Cases selected by the researcher were believed to be able to give some specialized insight on an experience (Yegidis and Weinbach, 1996:122).

\section{Sample Population}

The population in this study were the first year nursing students who had had no previous exposure to the clinical learning environment (ie. had not nursed previously).

\section{Sampling criteria}

The sample population selection criteria were as follows: The participants:

- were 18 years and older.

- $\quad$ had attended the complete orientation programme as designed by the Department of Nursing Science, University of Port Elizabeth.

- $\quad$ were English (Xhosa speaking participants included) or Afrikaans speaking to avoid loss of information during the process of interpreting interviews.

- had fulfilled practical hours in the clinical learning environment for at least 8-12 weeks prior to the interview.

- $\quad$ had been allocated to at least 2 different areas in which they had fulfilled practical requirements e.g surgical unit, medical unit.

- $\quad$ represented different gender groups (ie. male and female first year nursing students).

\section{Method of data collection}

Data was collected by means of unstructured phenomenological interviews. The data gathering was done by the researcher. An audiotape recorder was utilized to capture data in the interviews and they were transcribed verbatim. A separate personal journal was kept for process documentation. Directly following each interview, field notes were made about the interview situation. The central question asked of each student was:

"Tell me how you experience your practicals in the hospital." A pilot study was conducted with a first year nursing student who met all the criteria as mentioned. This was done to identify potential research problems during the first phase.

\section{Phenomenological strategy of enquiry}

The phenomenological approach focuses on individual's interpretations of their lived experiences and the ways in which they express them (Parahoo, 1997:395). Phenomenology is an approach to human inquiry that emphasizes the complexity of human experience and the need to study that experience holistically as it is actually lived (Polit and Hungler, 1997:442).

\section{Data analysis}

Interviews were transcribed verbatim and analyzed by the re- 
Table 1: Criteria to ensure trustworthiness

\begin{tabular}{|c|c|c|c|}
\hline $\begin{array}{l}\text { Criteria to ensure } \\
\text { Trustworthiness }\end{array}$ & Strategy & Criteria & Application \\
\hline Truth Value & Credibility & $\begin{array}{l}\text { Prolonged } \\
\text { Involvement }\end{array}$ & $\begin{array}{l}\text { Contact with the first year nursing students prior to the } \\
\text { interview to build rapport with them. }\end{array}$ \\
\hline Truth value & Credibility & $\begin{array}{l}\text { Persistent } \\
\text { Observation } \\
\text { Triangulation } \\
\\
\text { Peer } \\
\text { Debriefing }\end{array}$ & $\begin{array}{l}\text { An independent coder skilled in the field of research will } \\
\text { identify themes together with the researcher } \\
\text { Information is gathered from the interviews and field notes } \\
\text { it is then verified through the literature control, this is done } \\
\text { to determine if similar experiences have been identified } \\
\text { through various other studies. Data will then be analyzed } \\
\text { by the researcher and an independent coder skilled in the } \\
\text { field of research } \\
\text { An independent coder skilled in the field of research will } \\
\text { analyze data }\end{array}$ \\
\hline Truth Value & Credibility & Member Checks & $\begin{array}{l}\text { Discussions with colleagues will take place as a form of } \\
\text { member checking, and follow-up interviews will be held } \\
\text { with participants after themes have been identified. This } \\
\text { is to ensure that the data has been interpreted accurately }\end{array}$ \\
\hline Applicability & Transferability & Dense Description & $\begin{array}{l}\text { A complete description of methodology, including litera- } \\
\text { ture control to maintain clarity will be used. Guidelines de- } \\
\text { veloped will also be discussed in detail }\end{array}$ \\
\hline Consistency & Dependability & $\begin{array}{l}\text { Dense Description } \\
\text { Stepwise } \\
\text { Replication } \\
\text { Code/re-code } \\
\text { Procedure } \\
\text { Peer Examination }\end{array}$ & $\begin{array}{l}\text { A complete description of methodology, including litera- } \\
\text { ture control to maintain clarity will be used. Guidelines } \\
\text { developed will also be discussed in detail } \\
\text { The use of an independent coder skilled in the field of re- } \\
\text { search will analyze the study and discuss findings with the } \\
\text { researcher } \\
\text { The data will be left for two weeks after initial analysis and } \\
\text { the recorded. Identified themes will be compared } \\
\text { Consensus discussion between the researcher and the in- } \\
\text { dependent coder }\end{array}$ \\
\hline Neutrality & Confirmability & $\begin{array}{l}\text { Triangulation } \\
\text { Reflexivity }\end{array}$ & $\begin{array}{l}\text { Please see above } \\
\text { Objectivity will be maintained throughout the study, no } \\
\text { names of participants will appear anywhere }\end{array}$ \\
\hline
\end{tabular}

(Compare Krefting, 1991:214-222)

searcher and an independent coder. Interviews were analyzed for the emergence of themes that were prevalent amongst all participants. Data was reduced until the central storyline, as told by the student, emerged clearly from the raw data. A meeting was held between the researcher and the independent coder to reach consensus on the storyline and themes. The data was then analyzed by making use of the descriptive analysis technique by Tesch in (Creswell, 1994:155) and identified themes were formulated.

\section{Literature control}

The findings of the research was discussed by consulting relevant literature obtained from similar studies conducted as a source of verification of findings of the study and other related research.

\section{Trustworthiness}

Guba's Model in Krefting was utilized for ensuring trustwor- 
thiness in this study. This model defines different strategies of assessing the criteria mentioned below. These strategies are important to researchers in designing ways of increasing the rigor of qualitative studies and for readers to use as a means of assessing the value of the findings of qualitative research (Krefting, 1991:215).

\section{Truth Value}

This asks how confident the researcher is with the truth of the findings based on the research design, informants and context. Truth value is obtained from the discovery of human experience as lived and experienced by the informants. The strategy for establishing truth value is credibility (Krefting, 1991: 215). Actions to improve the credibility of the study include prolonged involvement, persistent observation, triangulation and peer debriefing.

\section{Applicability}

Applicability refers to the degree to which the findings can be applied (fitted) to other contexts and settings or with other groups. The criterion against which applicability is assessed is fittingness or transferability (Krefting, 1991:216)

\section{Consistency}

Consistency of data refers to whether the findings would be consistent if the enquiry were replicated with the same subjects or in similar context this is based on the criterion of dependability (Krefting, 1991: 217).

\section{Neutrality}

This refers to the degree to which the findings are a function solely of the informants and the conditions of the research and not of other biases, motivations and perspectives. Confirmability is the criterion against which neutrality can be measured (Krefting, 1991: 217).

\section{Ethical considerations}

The ethical principles stated by Crabtree and Miller (1999:83) were considered throughout the research study. These are: discomfort and harm, informed consent, confidentiality, privacy and anonymity. The right to full disclosure was also considered as an ethical principle. This means that the researcher fully described the nature of the study. The student had the right to refuse participation and withdraw from the study at any time. However, all students persevered throughout the study. Informed consent was obtained from the student prior to commencement of the interviews.

\section{Identified themes / results of the study}

One central theme identified that the student experiences uncertainty due to the lack of opportunities to develop competence in the providing of nursing care.

\section{Discussion of themes}

\section{Central theme: The student experiences uncertainty due to the lack of opportunities to develop competence in providing nursing care}

In education and nursing it is a known phenomenon that practice experience is a vital aspect of learning. Studies done by Parkes (1985:950), and Jones and Johnston (1997:476) on the distress, stress and coping of first year student nurses, found that initial placement in a clinical environment produces greater anxiety for students than at any other stage of their training. Sub-themes identified from the central theme are discussed as follows:

\section{Table 2: Identified themes related to the experiences of first year student nurses in the clinical learning environment}

\begin{tabular}{|l|l|}
\hline Central theme & Sub-themes \\
\hline $\begin{array}{l}\text { The student experiences uncertainty } \\
\text { due to the lack of opportunities to de- } \\
\text { velop competence in providing nursing } \\
\text { care }\end{array}$ & $\begin{array}{l}\text { Students felt insecure because they were not developing adequate nursing } \\
\text { skills due to unavailability and inaccessibility of staff }\end{array}$ \\
$-\begin{array}{l}\text { Students expressed helplessness and frustration due to the shortage and/or } \\
\text { absence of equipment to fulfil nursing duties and meet the needs of the } \\
\text { patients }\end{array}$ \\
$\begin{array}{l}\text { Students expressed confusion because of the conflict in the expectations of } \\
\text { the nursing school lecturers versus those of the hospital staff, related to the } \\
\text { performance of first year nursing students in the clinical environment }\end{array}$ \\
$\begin{array}{l}\text { Students experienced the nature of the clinical learning programme as } \\
\text { disrupting the continuity of patient care learning experiences }\end{array}$ \\
Students felt insecure because of the lack of guidance and support by \\
nursing personnel in the clinical learning environment
\end{tabular}




\section{Sub-theme: Students felt insecure in their practising of nursing skills, because they are not developing adequate skills, due to unavailability and inaccessibility of staff}

The factors which contribute towards the students feeling insecure because they are not developing adequate skills, are:

\section{Time Constraints}

The student must become familiar with the general functioning of the ward, which means that an orientation programme should be available in the nursing unit. One of the main functions of an orientation programme is to reduce fears and uncertainties.

During the interviews most of the students said that professional personnel in the clinical area do not have time to orientate them when they are in the clinical area for the first time. The insecurity experienced by students however, is mainly related to staff shortage and time constraints. A student verbalized the following:

"The first day when we arrived, they were very short-staffed and didn't have time to show us around where the sluice-rooms were or where anything was. We were told to get or fetch things and we didn't even know, everyone was so busy, it was the worst day I've ever had in the hospital so far."

\section{Students experience a reality shock due to lack of sufficient orientation and induction to the new learning environment}

Reality shock is described by Shin (2000:261) as the impact of the realization by the students that practice in the clinical setting is quite different from what they had expected or even imagined. The reason for this being, that students have practical skills demonstrated to them in a simulated environment before they are placed in the actual patient setting. A factor contributing to the insecurity that students experience is that he/she has to rapidly learn to cope with realities surrounding life and death situations with which they are confronted in the clinical environment, and at most times unexpectedly, as the students have verbalized:

"When I got into hospital I wasn't expecting what I got ... these are real patients ..."

"The whole thing of being stuck in your comfort zone and not wanting to step out of it ... I didn't expect what I was exposed to ..."

\section{Opportunities for students to assist each other to acquire/practise skills are not allowed to be utilized}

Time constraints is considered as one of the reasons for this. Another reason is that the value of the "buddy system" as a support system is underestimated and not considered as a possibility for acquiring of nursing skills.

Students verbalized that they are not getting the opportunity to practise skills with each other because the wards were either too busy, or the staff would say they are taking too long. At times when the wards are quiet, students are also not allowed to assist each other, because they are expected to fulfil other functions in the ward.

"We do things together and the sisters get upset, and think we are loafing around and socializing all the time, actually we are just helping each other, not doing anything wrong, sometimes I get the feeling that they don't trust us ... like we are not doing what they want us to do ... but we are."

\section{Attitudes of professional personnel towards first year nursing students}

The attitudes of the professional personnel influence the perception the students have of themselves. One of the biggest challenges the student nurse has in her first year of training is to "fit in" with the social environment of the clinical field, and to be accepted by personnel in the wards where they are doing practicals and participating in patient care. In this research study it was observed that first year students feel rejected and isolated. They felt as if they were a nuisance and a waste of time. This can be seen in the following quotation

"The sister thinks you are a nuisance in her eyes, and doesn't want anything to do with students ... some don't like students ... sometimes I can understand why they don't have time for us, or don't like us because we have just started, they have been nursing for many years and we are new."

\section{Sub-theme: Students expressed helplessness and frustration due to the shortage and/or absence of equipment to fulfil nursing duties and meet the needs of the patients}

The reality of nursing practice and the resources available in the clinical learning environment make it almost impossible to apply the principles of nursing care to obtain optimal results. Throughout the interviews students stated that due to shortage and/or absence of equipment they could not meet the needs of the patients and this resulted in feelings of helplessness and frustration.

"I feel frustrated and helpless. You stand there, you see this patient who really, really needs something and you can't help ... you have to do a dressing, it hasn't been changed for two days, it's absolutely necessary because you can take the dressing off, but you can put nothing on ... there's no dressing packs, ... nothing sterile ..."

Financial constraints on healthcare exacerbate this situation as personnel become frustrated and despondent with their lack of resources, leaving them with little energy to deal effectively with students (Stewart Faller, Dowell and Jackson, 1995:347). It was evident throughout the interviews that there are no disinfectants or soap with which to disinfect and clean the wards and equipment. One of the student's verbalized:

"There's no cleaning ingredients to clean and disinfect anything ... the floors are washed with water, I feel helpless, because I know' the risk of infection in a hospital ..."

Students are unable to meet the needs of patients which is contradictory to expectations of the programme where students are taught to maintain basic hygiene and care for patients with unique disease conditions

This is evidenced by the following extract from an interview: 
"Like we get taught to put the patient with dyspnoea in Fowler's position, but some beds are broken. and cannot wind up. I feel totally helpless..."

\section{Sub-theme: Students expressed confusion because of the conflict in the expectations of the nursing school lecturers versus those of the hospital staff, related to the performance of first year nursing students in the clinical environment}

Throughout the interviews students indicated that there was a lack of awareness amongst senior professionals of the needs and problems of first year students in the wards. They verbalized that everyone in the wards assumed that they knew what to do.

It became clear that there is a lack of understanding of first year students' needs for unconditional guidance and support because everything is so new to them.

\section{Lack of awareness amongst senior professionals of the needs and problems of first year students}

The lack of awareness of the needs and problems of first year students is substantiated by the following extract from an interview:

"... everyone in the ward expects me to know ... I thought it would be easier, it was mind-blowing ... you go to the ward and they expect you to know why..."

Hayes-Christiansen (1988:15) supports this by stating in his study that students enter nursing with an idealism most of us have forgotten, yet with a fear of being expected to know what to do before they have ever given themselves a chance to learn, or beîore a chance has been given to them to learn.

Furthermore, students experience confusion because of the discrepancy between what is taught to them in the classroom and what is actually being implemented in the clinical environment. They become very nervous when their clinical tutors/ mentors approach them to practise skills related to nursing care. This is because they try to recall what they were taught, whilst being used to the way nursing care is done in the actual clinical setting.

"I try to remember how we are taught ... because I'm now used to doing like they do in the hospital, and I'm always shaking and confused when Mrs ... and Mrs ... (clinical tutors) come to see me."

When clinical tutors arrive, it is a matter of survival on behalf of the student, because of the experience of trying to remember the way they were taught by academic mentors (compare Nolan 1998:626). A study done by Craddock (1993:219) maintains that students are more likely to adopt hospital rituals to reduce anxiety levels, and Melia (1987:334) states that the student may abandon many goals in favour of meeting the requirements of the moment, if it means she will be seen as part of the team.

Students verbalized that they receive no guidance from personnel in the wards as to their method of nursing care skills.

"They don't tell us it's different, they just sort of laugh at us and think there go the little fools again ... I feel quite embarrassed."

Students experience little support from personnel when they try to practise as they have been taught at the nursing school. This is evident in the following statement:

"The sisters say it's funny when we do things, some just shout and others ignore us."

\section{Inappropriate utilization of practice time}

Clinical practica hours are hours during which the student is placed in health service areas and exposed to the clinical learning opportunities with the aim of developing nursing skills and rendering patient care. Students indicate that they spend a lot of this time performing non-nursing activities which prohibit them from developing adequate nursing skills. Students stated that it was almost expected of them to assist and carry out functions that are not within the scope of the academic or the practical programme. When they were unwilling to perform these non-nursing duties they were ostracized leading to feelings of hurt. One student stated:

"At the moment the general assistants just want us to... there's a whole big thing about taking plates to the kitchen, and ... um, dishing up food. If we are busy with something else, they get cross because they think we should like, ... um, be helping them dishing up food and, I mean, it is hectic in the wards. One of them said to us, "these children are lazy, thev don't want to help us, they want to do their own thing". We were actually busy, I was actually doing an enema at the time ..."

Students were of the opinion that they were not spending enough time with the patients, as most of their time is spent on activities that should be done by non-nursing members of the health team, as stated by the students in this study.

"I'm frustrated, sometimes dusting windows when I must be doing blood pressures. We don't have a say because the sisters say we must do it, the general assistants are not here sometimes, I don't know what's going on ... we must do dishes and that ..."

\section{Sub-theme: Students experience the nature of the clinical learning programme as disrupting the continuity of patient care learning experiences}

Continuity of patient care in the clinical environment refers to the process of initial care from admission to the hospital and the unit, the follow-through care that is received during the stay in hospital, up to the stage of discharge from the hospital.

Due to the nature of the academic programme, students are placed in the clinical environment for two half days a week. First year students rotate on a two monthly basis, ie. they are placed in a different clinical area every two months during the first year of study. The break due to the two monthly allocation rotations add to students' experiences of anxiety and uncertainty.

"It's really funny going from one ward to another .. um .. also the ward systems change, the routine, not the whole routine, like you have to shift around it ... it's really scary because you have to learn new things all over again ..." 
Students stated that because of the break in between contact days with patients, they are unable to develop a nurse-patient relationship or follow through a disease pattern from the initial onset through to the end/final stages.

\section{Sub-theme: Students feel insecure because of the lack of guidance and support by nursing personnel in the clinical learning environment}

The students in the study believed that they are not adequately informed of the daily responsibilities required of them to develop nursing skills and practice. They arrive on duty and there is little or no communication between the ward personnel and the student as to where they must begin the daily practical tasks and patient care activities.

\section{Patient allocation}

Patient allocation ensures that the workload of the ward and the patient care activities are equally divided amongst staff members and that prescribed nursing care is effectively implemented. The patient allocation is the responsibility of the reg- istered nurse in charge of the ward for the day. This is not materializing as verbalized by a student:

"... I still don't know' some places existed when they ask me to do things in the ward, but also today I never found out that I was supposed to be working in a specific ward and I just saw my name on the board. No-one told me. I felt like no-one was communicating to us, especially me because I was supposed to be in that ward. Someone shouted that there was something, something wasn't done and I was in charge of that ward. I didn't see my name anywhere."

\section{Communication}

The bulk of the information concerning the patients' condition and treatment plan is discussed in a ward round each morning and afternoon when shifts change. Ward rounds may take place more often, depending on the condition of the patient. The information is usually shared by utilizing a multi-disciplinary team approach. The reason for this approach is the requirement of total patient care and sharing of observations,

\section{Table 3: Guidelines to optimize accompaniment}

\begin{tabular}{|c|c|c|c|}
\hline \multicolumn{2}{|c|}{ Major Guidelines } & \multicolumn{2}{|c|}{ Sub-guidelines } \\
\hline 1. & $\begin{array}{l}\text { Decrease and alleviate feelings of in } \\
\text { security }\end{array}$ & . & $\begin{array}{l}\text { Establishment of a relationship of trust between accompanier and } \\
\text { student by: } \\
\text { Promoting awareness of recognition, ie. recognition of the } \\
\text { student's: } \\
\text { - } \quad \text { identity } \\
\text { - unique individuality } \\
\text { - background, life history, experiences } \\
\text { - individual personal rights } \\
\text { - Creating awareness of understanding } \\
\text { Creating awareness of trust } \\
\text { - } \quad \text { awareness of acceptance } \\
\text { - protection of dignity } \\
\text { - observing performance and competence } \\
\text { Promote participative learning by: } \\
\text { - } \quad \text { Enhancing students' awareness of acceptance and belonging in } \\
\text { - } \quad \text { the clinical learning environment } \\
\text { Requiring students to take responsibility } \\
\text { Developing resources for learning and evaluation of outcomes } \\
\text { Developing and operationalising a "buddy" or peer support } \\
\text { system } \\
\text { Developing and managing orientation programmes }\end{array}$ \\
\hline 2. & $\begin{array}{l}\text { Ensure a student sup-port system for } \\
\text { clinical practice purposes }\end{array}$ & 2.1 & $\begin{array}{l}\text { Provision of a counselling service } \\
\text { Facilitating maximum availability and accessibility of the lecturer }\end{array}$ \\
\hline 3. & $\begin{array}{l}\text { Eliminate conflicting expectations of } \\
\text { nursing school lecturers versus } \\
\text { those of hospital staff }\end{array}$ & $\begin{array}{l}3.1 \\
3.2\end{array}$ & $\begin{array}{l}\text { Availability of clear, relevant policies and guidelines } \\
\text { Involvement of personnel in the accompaniment of students }\end{array}$ \\
\hline
\end{tabular}


interpretations and advice by persons with the expertise and relevant experience. This serves as a vital learning opportunity for the first year nursing student. Communication, however, appears to be a stumbling block in the process, because professional personnel often do not take time to explain the treatment plan and condition of the patient. A student verbalized:

"When you go on rounds they speak like in morse code really, and they speak so fast ... they never explain to us ..."

\section{Lack of supervision}

Supervision is an interpersonal process whereby a skilled/experienced individual assists, educates and supports a less experienced person to achieve professional abilities (compare Magg in Fowler, 1996:476; Barber and Norman in Rodriguez and Goorapah, 1998:663).

Students shared in the interviews that because they were new, they needed somebody to "check" them whilst rendering patient care and practising skills. A student verbalized:

"Nobody ever checks on us -they still don't check on us, if we're doing everything the right way ... because I'm so new and very conscientious, I lack the confidence and I'd like to be checked by somebody competent, to see if I'm on the right track ..."

\section{Guidelines to optimize} accompaniment of first year nursing

\section{Students in the clinical learning environment}

Data analyzed from the interviews indicated that students feel insecure due to the lack of guidance and support by nursing personnel in the clinical learning environment. The guidelines formulated which will optimize accompaniment of first year nursing students were discussed under the headings of table 3.

\section{Limitations of the study}

The following limitations of the study were identified:

- Interviews were conducted with students from a single state hospital in the Nelson Mandela Metropole.

- The study does not include the experiences of students allocated to other state hospitals or private hospitals for clinical practice.

\section{Recommendations}

\section{Recommended Research}

The limitations of the study have been indicated. In the light of that and the findings of the study, the following is recommended for future research in this regard:

- Further research can be implemented regarding the nature of student/health service personnel relationships, its impact on student learning, and means of empowering nursing students in their mastering of health care knowledge, nursing skills and the socializing into the role of the professional nurse.

\section{Recommendations related to Nursing Education}

To ensure that improved strategies are in place for quality clinical teaching the following areas need to be addressed:

- Agreements between nursing schools and health service authorities must include assistance with accompaniment of nursing students in the clinical health environment.

- Agreements between nursing schools and health service authorities should make provision for formalizing the nature of the contribution of clinical nursing personnel in the nursing programme.

\section{Recommendations related to Nursing Practice}

The research results indicate that students are receiving very little, if any, support and guidance from personnel in the clinical learning environment.

- Courses and workshops to improve the quality of clinicalteaching, clinical accompaniment and clinical assessment should form part of the annual personnel development programme of clinical health service staff, with nursing school personnel contributing to such programmes.

- Clinical teaching, assessment and accompaniment of students should officially be part of the responsibility schedule and job description of registered nurses in training hospitals.

\section{Conclusion}

The study produced evidence that there are definite reasons why the first year students experience the clinical learning environment as anxiety-provoking. The quality of learning in the first academic year is crucial as a foundation for the rest of the basic nursing programme. Particular attention should therefore be given to content and strategies to secure adequate learning opportunities, as well as a learning environment conducive to the attainment of outcomes expected of the nursing student.

The nursing student is the future provider of competent, safe nursing care and needs to be empowered through effective accompaniment to reach the basic nursing programme outcomes, namely that of -

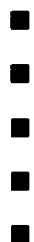
independent practitioner.
manager of patient care.
teacher of health and nursing skills.
beginner health unit manager.
researcher. 


\section{Bibliography}

SOUTH AFRICA (REPUBLIC) 1991: Regulations related to the Scope of Practice of Registered Nurses. Regulation R.2598 in terms of the Nursing Act, 1978 (Act no. 50, 1978, as amended). Pretoria: government printer.

SOUTH AFRICAN NURSING COUNCIL: Terminology List. 50 years. 1944-1994. Pretoria.

BURNS, N \& GROVE, SK 1999: Understanding Nursing Research. $2^{\text {nd }}$ Edition. USA: Saunders Company.

CRABTREE, BF \& MILLER, WL 1999: Doing Qualitative Research. $2^{\text {nd }}$ Edition. United Kingdom: Sage.

CRADDOCK, E 1993: Developing the Facilitator Role in the Clinical Area. Nurse Education Todav. 13(3): 217-224.

CRESWELL, JW 1994: Research design: Qualitative and Quantitative Approaches. London: Sage Publications

FORREST, S; BROWN, N \& POLLOCK, L 1996: The Clinical Role of the Nurse Teacher. Journal of Advanced Nursing. 24: 1257-1264.

FOWLER, J 1996: The Organization of Clinical Supervision within the Nursing Profession: A Review of the Literature. Journal of Advanced Nursing. 23: 471-478.

HARVEY, VC \& MURRAY, NE 1997: Students' Perceptions of Nursing. Journal of Nursing Education. 36(8): 383-388.

HAYES-CHRISTIANSEN, CV 1988: The Beginning Student: A Faculty Challenge. Nurse Educator. 13(1): 14-15.

JONES, MC \& JOHNSTON, DW 1997: Distress, Stress and Coping in First Year Student Nurses. Journal of Advanced Nursing. 26: 470-476.

KOTZÉ, WJ 1998: An Anthropological Nursing Science, Nursing Accompaniment Theory. Health SA. 3(2): 3-14.

KREFTING, L 1991: Rigor in Qualitative Research: The Assessment of Trustworthiness. American Journal of Occupational Therapv. 45(3): 214-222.

MELIA, K 1987: Learning and Working: The Occupational Socialisation of Nursing. London: Tavistock Publications.

MELLISH, JM \& BRINK, HIL 1990: Teaching the Practice of Nursing. $3^{\text {rd }}$ Edition. Durban: Butterworths.

NOLAN, C 1998: Learning on Clinical Placement: The Experience of Six Australian Student Nurses. Nurse Education Today. 18: 622-629.

PARAHOO, K 1997: Nursing Research. Principles. Processes and Issues. Great Britain: Mac Millan Press.

PARKES, KR 1985: Stressful Episodes Reported by First
Year Student Nurses: A Descriptive Account. Social Science Medicine. 20(9): 945-953.

POLIT, DF \& HUNGLER, BP 1997: Essentials of Nursing Research, Methods, Appraisal and Utilization. $4^{\text {th }}$ Edition. Philadelphia: J. B. Lippincott Company.

RODRIGUEZ,P \& GOORAPAH,D 1998: Clinical Supervision for Nurse Teachers: The Pertinent Issues. British Journal of Nursing. 7(11): 663-669.

SHIN, KR 2000: The Meaning of the Clinical Learning Experiences of Korean Nursing Students. Journal of Nursing Education. 39(6): 259-265.

STEWART FALLER, H; DOWELL, MA \& JACKSON, MA 1995: Bridge to the Future:Non-Traditional Clinical Settings, Concepts and Issues. Journal of Nursing Education. 34(8): 344-349.

YEGIDIS, B \& WEINBACH, RW 1996: Research Methods for Social Workers. $2^{\text {nd }}$ Edition. London: Allyn and Bacon. 